\title{
Multi-Walled Carbon Nanotube-Assisted Encapsulation Approach for Stable Perovskite Solar Cells
}

\author{
Jin-Myung Choi ${ }^{1,2}$, Hiroki Suko ${ }^{3}$, Kyusun Kim ${ }^{1}$, Jiye Han ${ }^{1,2}$, Sangsu Lee ${ }^{1,2}$, Yutaka Matsuo ${ }^{3,4}$, \\ Shigeo Maruyama ${ }^{3}{ }^{\circledR}$, Il Jeon ${ }^{1,2, *(1)}$ and Hirofumi Daiguji ${ }^{3, *}$
}

1 Department of Chemistry Education, Graduate School of Chemical Materials, Crystal Bank Institute, Pusan National University, Busan 46241, Korea; csj356093@gmail.com (J.-M.C.); ewrb23@gmail.com (K.K.); hanyksw20@naver.com (J.H.); ssang94@naver.com (S.L.)

2 Department of Nano Fusion Technology, Pusan National University, Busan 46241, Korea

3 Department of Mechanical Engineering, School of Engineering, The University of Tokyo, Tokyo 113-8656, Japan; suko.ut.mech@thml.t.u-tokyo.ac.jp (H.S.);

yutaka.matsuo@chem.material.nagoya-u.ac.jp (Y.M.); maruyama@photon.t.u-tokyo.ac.jp (S.M.)

4 Department of Chemical System Engineering, Graduate School of Engineering, Nagoya University, Nagoya 464-8603, Japan

* Correspondence: il.jeon@spc.oxon.org (I.J.); daiguji@thml.t.u-tokyo.ac.jp (H.D.)

Citation: Choi, J.-M.; Suko, H.; Kim, K.; Han, J.; Lee, S.; Matsuo, Y.;

Maruyama, S.; Jeon, I.; Daiguji, H.

Multi-Walled Carbon Nanotube-

Assisted Encapsulation Approach for Stable Perovskite Solar Cells.

Molecules 2021, 26, 5060. https://

doi.org/10.3390/molecules 26165060

Academic Editor: Federico Bella

Received: 15 July 2021

Accepted: 17 August 2021

Published: 20 August 2021

Publisher's Note: MDPI stays neutral with regard to jurisdictional claims in published maps and institutional affiliations.

Copyright: (c) 2021 by the authors. Licensee MDPI, Basel, Switzerland. This article is an open access article distributed under the terms and conditions of the Creative Commons Attribution (CC BY) license (https:// creativecommons.org/licenses/by/ $4.0 /)$.

\begin{abstract}
Perovskite solar cells (PSCs) are regarded as the next-generation thin-film energy harvester, owing to their high performance. However, there is a lack of studies on their encapsulation technology, which is critical for resolving their shortcomings, such as their degradation by oxygen and moisture. It is determined that the moisture intrusion and the heat trapped within the encapsulating cover glass of PSCs influenced the operating stability of the devices. Therefore, we improved the moisture and oxygen barrier ability and heat releasing capability in the passivation of PSCs by adding multi-walled carbon nanotubes to the epoxy resin used for encapsulation. The $0.5 \mathrm{wt} \%$ of carbon nanotube-added resin-based encapsulated PSCs exhibited a more stable operation with a ca. 30\% efficiency decrease compared to the ca. $63 \%$ decrease in the reference devices over one week under continuous operation. Specifically, the short-circuit current density and the fill factor, which are affected by moisture and oxygen-driven degradation, as well as the open-circuit voltage, which is affected by thermal damage, were higher for the multi-walled carbon nanotube-added encapsulated devices than the control devices, after the stability test.
\end{abstract}

Keywords: perovskite solar cells; carbon nanotubes; encapsulation; passivation; packaging; epoxy resin

\section{Introduction}

Organohalide perovskite materials have attracted considerable attention, especially in the application of energy harvesting [1,2]. When applied in photovoltaics, these materials yield a high-power conversion efficiency owing to their outstanding properties, namely their wide range of light absorption and long exciton diffusion length $[3,4]$. Despite the high efficiency of perovskite solar cells (PSCs), insufficient device stability has been the limiting factor in commercialisation. Moreover, the perovskite materials have been reported to degrade easily due to moisture [5], oxygen [6,7], ultra-violet (UV) light, trapped charge [8,9], and heat [10-12]. While most researchers have focused on improving the stability of perovskite materials against moisture, it is noteworthy that good packaging technology can prevent water and oxygen intrusion before degradation occurs in the material [13]. The other aforementioned adverse factors can be resolved using UV-cutting glass and chargetransporting materials with a low chemical capacitance $[8,9]$. However, the thermal damage is difficult to circumvent in such an encapsulated system because the heat is trapped inside the encapsulating glass. As most of the known electronics utilise encapsulation, it is evident that the PSCs will inevitably be encapsulated, which confines the device system. The confinement works favourably in the perspective of moisture and oxygen barriers but 
unfavourably in heat release. Therefore, it is desirable to develop an encapsulation system that blocks moisture and oxygen as much as possible while releasing heat to the furthest extent. A cover glass is used in any type of encapsulation system, as it is a perfect barrier for both moisture and heat. This implies that the leakage occurs where the UV curable epoxy resin is placed [14-17]. Thus, the performance of encapsulation is determined by the barrier ability of the epoxy resin. Accordingly, many efforts have been made to develop epoxy resins with better barrier properties [18-20].

Since their discovery in 1991 [21], carbon nanotubes have been used in various applications owing to their exceptionally high electrical [22,23] and thermal conductivity [24,25] along the direction of the graphitic tubes. Moreover, carbon nanotubes are highly hydrophobic, with an average tube diameter less than the size of a water molecule, making it difficult for the water molecules to pass through the tubes [26,27]. In addition, the conjugated double bonds present in carbon nanotubes react with radicals, forming strong sigma bonds. This implies that adding carbon nanotubes to epoxy resins can improve the moisture barrier ability and increase thermal conductivity.

Herein, we report the addition of multi-walled carbon nanotubes (MWCNTs or MWNTs) to UV curable epoxy resin sealants used for the encapsulation of inverted-type PSCs, demonstrating improved moisture, oxygen barrier ability, and heat releasing properties. For the standardisation of the experiment, we tested the encapsulation with different structural approaches and applied pressures. The PSCs with MWNT (0.5 wt\%)-added encapsulants demonstrated a longer device lifetime than conventional devices. The stability data of the reference devices with no MWNTs showed a faster decrease in the short-circuit current density $\left(J_{\mathrm{SC}}\right)$, fill factor $(\mathrm{FF})$, and open-circuit voltage $\left(V_{\mathrm{OC}}\right)$ values over time. According to literature and experiments conducted in this work, the decreases in $J_{\mathrm{SC}}$ and $V_{\mathrm{OC}}$ originated from moisture intrusion [28-30] and thermal damage [12,30,31], respectively. While the degradation caused by moisture and oxygen was more dominant, damage by the trapped heat was insignificant enough to ignore. The addition of MWNTs to the UV epoxy resin alleviated the decrease in $J_{\mathrm{SC}}$ by ca. $21.5 \%$ and $\mathrm{FF}$ by ca. $43.5 \%$, which was attributed to the improved moisture and oxygen barrier ability. Furthermore, $V_{\text {OC }}$ became steady during the entire operation of the solar cells, indicating minimal thermal damage due to the excellent heat-releasing property of the $0.5 \mathrm{wt} \%$ MWNT-added UV resin-based encapsulation. The results indicated that incorporating the carbon nanotubes in encapsulation can serve as a gateway to minimising thermal damage and as a barrier to moisture and oxygen attack. Therefore, this study revealed the pathway to stable next-generation thin-film photovoltaic technology, towards the commercialisation of thin-film solar cells.

\section{Results and Discussion}

The inverted type PSCs were fabricated in the configuration of indium tin oxide (ITO)/ poly(triaryl amine) (PTAA)/perovskite/phenyl-C61-butyric acid methyl ester (PCBM)/ $\mathrm{C}_{60}$ /bathocuproine (BCP)/Ag (Figure 1a). The encapsulation process was standardised to make stability comparisons fair during tests. From our preliminary tests, we discovered that using desiccant, also known as 'getter', could reduce the UV light damage on the perovskite film during the curing process, functioning like UV masking tape (Figure S1 in Supplementary Materials). Therefore, we used the getter in all of our encapsulated devices. Based on this, three different structural encapsulation approaches were examined (Figure S2a-d). The cover glass (with and without a cavity) and the applied position of the UV epoxy resin were tested, and a UV curing time of 8 min was used. Different pressures were applied for each structure during the encapsulation (Figure S2e,f). The results showed that the cover glass with a cavity had the most stable operation when UV epoxy resin was applied on the edge, with the UV masking tape protecting the device (Figures S3 and S4). However, the device on which uncured epoxy resin was applied showed the worst device stability, revealing that uncured resin damaged the device (Figure S3c). In addition, all the devices encapsulated under hard pressure exhibited a much higher device stability. It is notable that the applied pressure was the most dominant factor in the device 
packaging (Figure 1b). Therefore, different specific weight pressures applied during the encapsulation, in particular $0 \mathrm{~N} \mathrm{~cm}^{-2}, 4.90 \mathrm{~N} \mathrm{~cm}^{-2}, 9.81 \mathrm{~N} \mathrm{~cm}^{-2}$, and $14.71 \mathrm{~N} \mathrm{~cm}^{-2}$, were tested. The epoxy resin thickness under different pressures was tested by crosssectional scanning electron microscopy (SEM) (Figure 1c). The thicknesses were $122 \mu \mathrm{m}$, $76.8 \mu \mathrm{m}$, and $72.8 \mu \mathrm{m}$ for $4.90 \mathrm{~N} \mathrm{~cm}^{-2}, 9.81 \mathrm{~N} \mathrm{~cm}^{-2}$, and $14.71 \mathrm{~N} \mathrm{~cm}^{-2}$, respectively. After the UV curing of samples, the device stability of the encapsulated samples was measured. Figure 2a shows that the devices with higher pressure, that is, thinner resin, exhibited greater device stability (Figure S5). Although the $9.81 \mathrm{~N} \mathrm{~cm}^{-2}$ pressure was sufficient to produce device encapsulation with good stability, the optimal pressure was $14.71 \mathrm{~N} \mathrm{~cm}^{-2}$. The current density-voltage $(J-V)$ curves of the encapsulated devices, with the applied pressures of $4.90 \mathrm{~N} \mathrm{~cm}^{-2}$ and $14.71 \mathrm{~N} \mathrm{~cm}^{-2}$ before and after one week of durability testing, are shown in Figure $2 \mathrm{~b}$ and $2 \mathrm{c}$, respectively. From the changes in the $J-V$ curves, we can observe that the $J_{\mathrm{SC}}$ and FF of the devices with an applied pressure of $4.90 \mathrm{~N} \mathrm{~cm}^{-2}$ decreased more significantly than the devices with an applied pressure of $14.71 \mathrm{~N} \mathrm{~cm}^{-2}$ after one week (Figure 2d,e; Table 1). Moreover, the decrease in $J_{S C}$ was reportedly linked to degradation by moisture [29]. When water molecules penetrated the epoxy resin and contacted the perovskite photoactive layer, the degradation of the perovskite layer was triggered; $\mathrm{NH}_{2} \mathrm{CHNH}_{2} \mathrm{PbI}_{3}\left(\mathrm{FAPbI}_{3}\right)$ dissociated to $\mathrm{FAI}$ and $\mathrm{PbI}_{2}$ by moisture and sunlight [11,30-33].

$$
\begin{gathered}
\mathrm{NH}_{2} \mathrm{CHNH}_{2} \mathrm{PbI}_{3} \rightarrow \mathrm{PbI}_{2}+\mathrm{CH}_{5} \mathrm{IN}_{2}, \\
\mathrm{NH}_{2} \mathrm{CHNH}_{2} \mathrm{PbI}_{3}+\mathrm{H}_{2} \mathrm{O} \rightarrow \mathrm{NH}_{2} \mathrm{CHNH}_{2} \mathrm{PbI}_{3} \mathrm{H}_{2} \mathrm{O}, \\
4\left(\mathrm{NH}_{2} \mathrm{CHNH}_{2} \mathrm{PbI}_{3}\right)+2 \mathrm{H}_{2} \mathrm{O} \rightarrow\left(\mathrm{CH}_{3} \mathrm{NH}_{3}\right)_{4} \mathrm{PbI}_{6} 2 \mathrm{H}_{2} \mathrm{O}+3 \mathrm{PbI}_{2} .
\end{gathered}
$$

\begin{tabular}{|c|c|c|c|c|c|}
\hline \multicolumn{2}{|l|}{ Device Type $\backslash$ Device Performance } & \multirow{2}{*}{$J_{\mathrm{SC}}\left[\mathrm{mA} / \mathrm{cm}^{2}\right]$} & \multirow{2}{*}{$V_{\text {OC }}[\mathbf{V}]$} & \multirow{2}{*}{ FF } & \multirow{2}{*}{ PCE [\%] } \\
\hline Feature & Stability Time & & & & \\
\hline Before encapsulation & $\mathrm{N} / \mathrm{A}$ & 19.4 & 0.94 & 64.8 & 11.8 \\
\hline \multirow{2}{*}{ Encapsulation by $4.90 \mathrm{~N} \mathrm{~cm}^{-2}$ pressure } & Initial & 11.3 & 0.97 & 28.67 & 3.15 \\
\hline & one week & 2.31 & 0.96 & 15.33 & 0.34 \\
\hline \multirow{2}{*}{ Encapsulation by $14.71 \mathrm{~N} \mathrm{~cm}^{-2}$ pressure } & Initial & 13.9 & 0.99 & 28.69 & 3.96 \\
\hline & one week & 8.63 & 0.85 & 26.72 & 1.96 \\
\hline \multirow{2}{*}{ Encapsulation with MWNT (0.5 wt\%)-added epoxy resin } & Initial & 16.7 & 0.92 & 61.90 & 9.51 \\
\hline & one week & 13.1 & 0.92 & 55.51 & 6.69 \\
\hline \multirow{2}{*}{ Encapsulation with MWNT (1.0 wt $\%$ )-added epoxy resin } & Initial & 16.8 & 0.99 & 39.08 & 6.50 \\
\hline & one week & 1.19 & 0.87 & 10.62 & 0.11 \\
\hline
\end{tabular}

Table 1. Packaging type of the devices and solar cell performance values before and after one week of durability testing. More detailed corresponding $J-V$ curves, EQE, and statistical information can be found in Figures S7, S15 and S16).

(a)

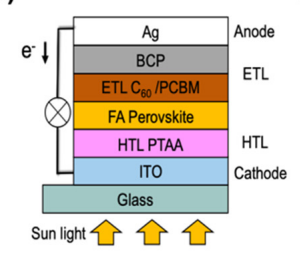

(b)

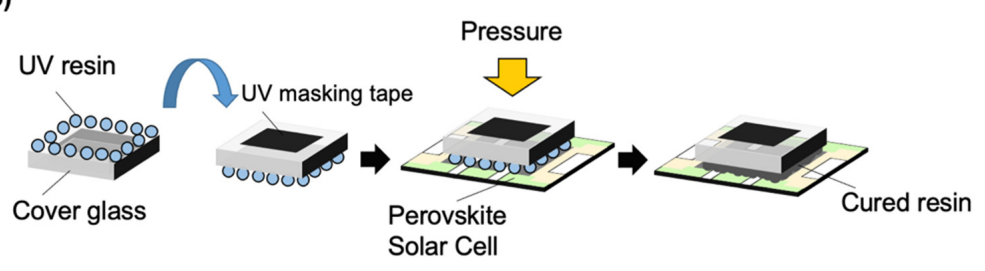

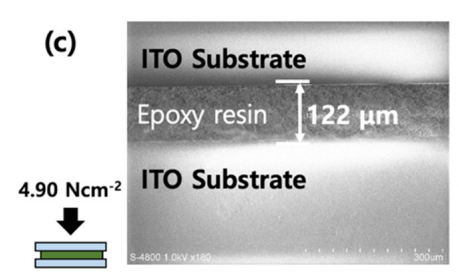

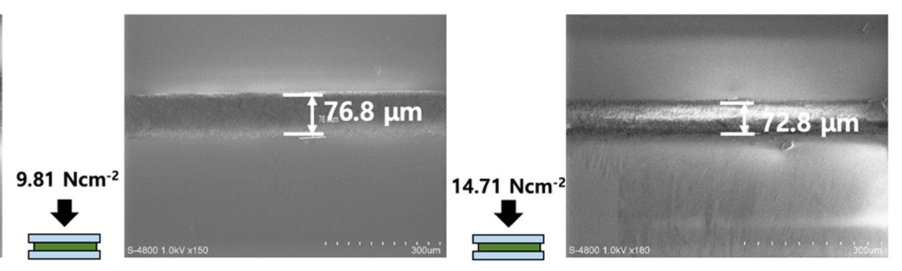

Figure 1. (a) Structure of an inverted PSC fabricated in this work; (b) packaging process using UV epoxy resin; (c) cross-sectional SEM images and thickness of the pressed UV-epoxy resin. 
(a)

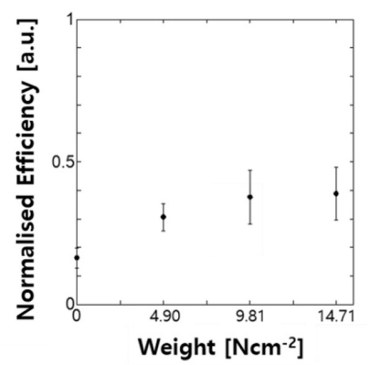

(d)

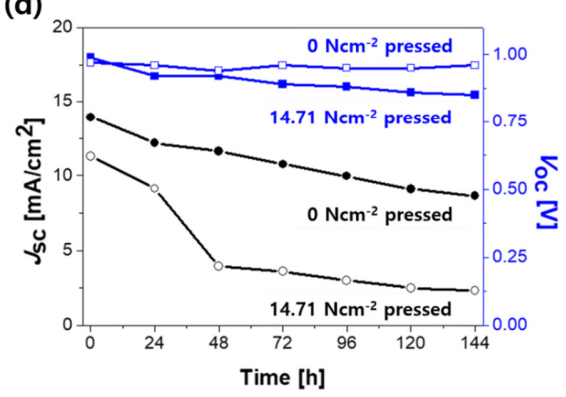

(b)

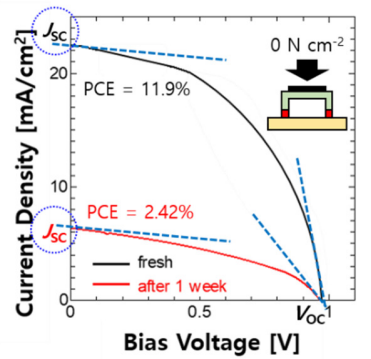

(c)

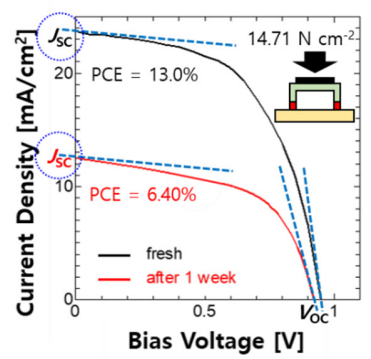

(e)

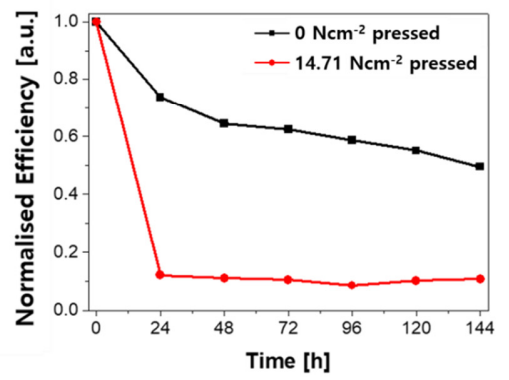

Figure 2. (a) Normalised efficiency drop of PSCs encapsulated under different applied pressures during the packaging process left in the atmosphere after one week; $(\mathbf{b}, \mathbf{c}) J-V$ curves of the encapsulated PSCs under (b) $0 \mathrm{~N} \mathrm{~cm}^{-2}$ and (c) $14.71 \mathrm{~N} \mathrm{~cm}^{-2}$ before and after being left in the atmosphere for one week; (d) changes in $J_{\mathrm{SC}}$ and $V_{\mathrm{OC}}$ of the devices encapsulated under the applied pressures of $0 \mathrm{~N} \mathrm{~cm}^{-2}$ and $14.71 \mathrm{~N} \mathrm{~cm}^{-2}$. (e) Decrease in the normalised efficiency during one week of the stability test for the PSCs encapsulated under the applied pressures of $0 \mathrm{~N} \mathrm{~cm}^{-2}$ and $14.71 \mathrm{~N} \mathrm{~cm}^{-2}$.

Due to such degradation, the light absorption coefficient of the perovskite layer decreased, which in turn decreased JSC. Additionally, the degradation of the perovskite was reported to increase the contact resistance at the perovskite interfaces between PTAA and PCBM [34]; this was reflected in the increase in the series resistance $\left(R_{S}\right)$ of our devices, which entailed a decrease in FF. Therefore, we can conclude that the moisture penetration through the UV epoxy resin was the main reason for the decrease in the $J_{\mathrm{SC}}$ and FF. As more moisture penetrates the devices encapsulated with the applied pressure of $4.90 \mathrm{~N} \mathrm{~cm}^{-2}$, more significant decreases in $J_{\mathrm{SC}}$ and FF were observed than in the devices with the applied pressure of $14.71 \mathrm{~N} \mathrm{~cm}^{-2}$.

The decrease in the open-circuit voltage $\left(V_{\mathrm{OC}}\right)$ of the devices was significantly smaller than that of the $J_{\mathrm{SC}}$ and FF during the durability test. The leakage current at the holetransporting layer (HTL) and the electron-transporting layer (ETL), causing hole-electron recombination, was reported to reduce $V_{\mathrm{OC}}[35,36]$. However, in this case, the $V_{\mathrm{OC}}$ decrease was not due to the leakage current as the shunt resistance values were almost the same. It was reported that thermal damage to the perovskite reduced $V_{\mathrm{OC}}$ [28,37-40]. Furthermore, the encapsulated devices with a stronger pressure of $14.71 \mathrm{~N} \mathrm{~cm}^{-2}$ resulted in a slightly greater $V_{\mathrm{OC}}$ loss after one week than the devices with a pressure of $0 \mathrm{~N} \mathrm{~cm}^{-2}$. Devices to which a nitrogen gun was constantly blown during the stability test to negate the heat damage, showed no $V_{\mathrm{OC}}$ loss either (Figure 56 ). Thus, we can reasonably deduce that the trapped heat caused the reduction in $V_{\mathrm{OC}}$ as good encapsulation did not only let the air and moisture out but also retained the heat. This implied that it was desirable to have a system that could block moisture and oxygen and release heat more effectively.

Therefore, the role of the UV epoxy resin is critical in exhibiting such properties. We introduced MWNTs into the UV epoxy resin to realise this. It has been reported that adding MWNTs improves the moisture and oxygen barrier ability and increases the thermal conductivity of the UV epoxy resin [41,42]. Accordingly, we added small amounts of MWNTs to the UV epoxy resin and tested its effect on the PSC operating stability. In the operation of solar cells, thermal damage also contributes to the degradation of PSCs. Therefore, it 
is important to monitor $V_{\mathrm{OC}}$, particularly by operating the device, to observe the effect of thermal damage. The thermal energy from sunlight is transferred into the solar cells through (1) low energy absorption, (2) an electrical operating point, (3) encapsulation heat trapping, and (4) solar energy that is heated during charge transport. Among them, the solar energy that is heated during the charge transport can be branched into $(\mathrm{A})$ thermalisation loss, (B) the junction/contact between layers, (C) radiative recombination, and (D) the thermal conductivity and resistance of materials (Figure 3a) [43,44]. These processes generate heat when the solar cells are operating. If the devices are well encapsulated, heat will be trapped, accelerating the degradation. The thermal damage to the solar cells results in a conspicuous decrease in $V_{\mathrm{OC}}$ and slight increase in $J_{\mathrm{SC}}$, with a slight decrease in FF according to the theory (Figure $3 b$ ) [45]. This implies that the device should be operated to monitor the thermal damage, reflected by the $V_{\mathrm{OC}}$ drop. Therefore, the device stability was tested by operating solar cells from this point onwards.

(a)
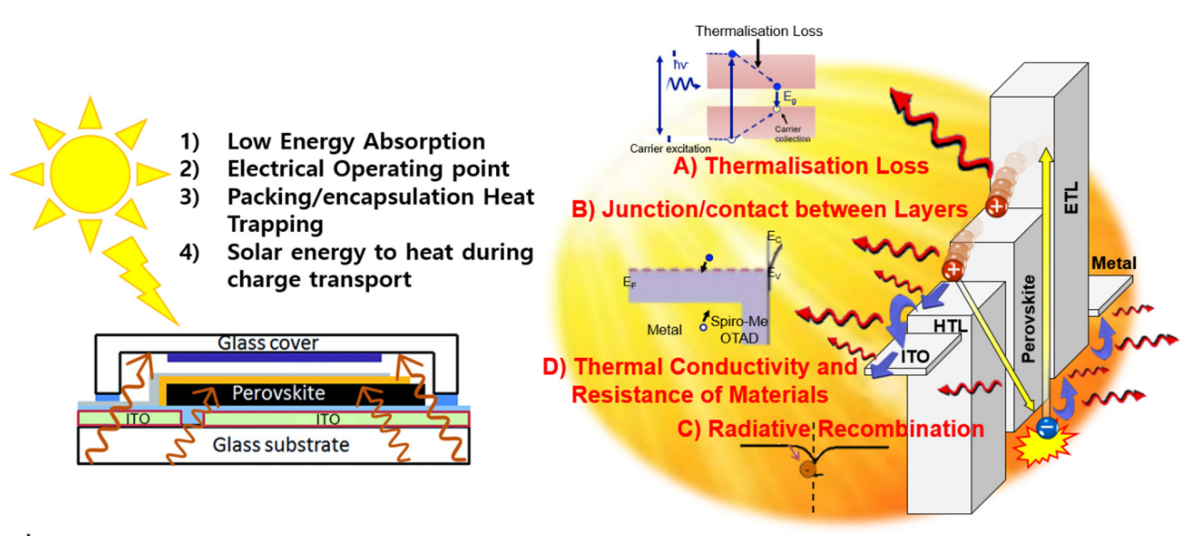

(b)
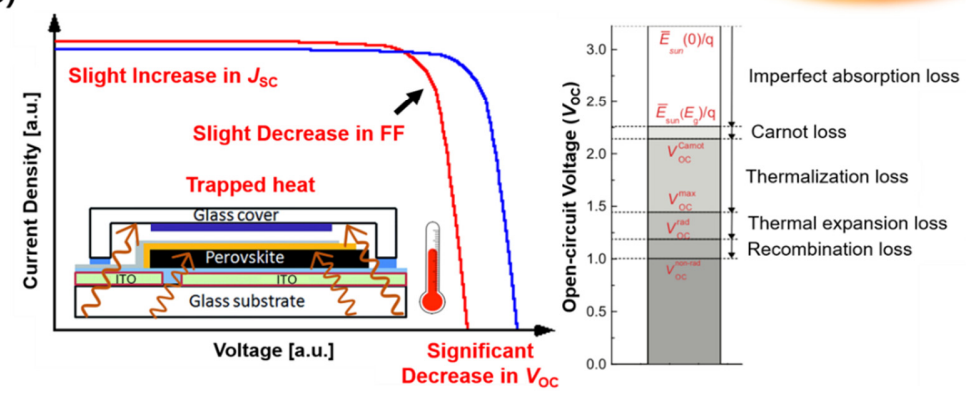

Figure 3. (a) Origin of the heat trap categorised by possible sources (left) and the detailed illustration of heat generation during the operation of PSC (right) (b) Mechanism of PSC degradation due to heat trapping during the PSC operation and the breakdown on the origin of the $V_{\mathrm{OC}}$ loss related to the change in photovoltaic performance of the PSC.

The MWNT-added UV epoxy resin was used in the packaging process to enhance the moisture barrier property, with the encapsulating pressure of $14.71 \mathrm{~N} \mathrm{~cm}^{-2}$ (Figure S8). Before fabricating PSCs, we wanted to consolidate the effect of the MWNT addition and find the optimal amount of MWNT. Therefore, we conducted water contact angle tests to confirm that the addition of MWNT increased the hydrophobicity of the UV epoxy resin. The water contact angle images of epoxy resin and MWNT-added UV epoxy resin are shown in Figure $4 \mathrm{a}$. The contact angle of the MWNT-added UV epoxy resin $\left(87.9^{\circ}\right)$ was larger than that of the bare epoxy resin $\left(81.1^{\circ}\right)$ [46]. For further investigation, water vapour transmittance rate (WVTR) and oxygen transmittance rate (OTR) tests were performed; they revealed the barrier ability against water and oxygen, respectively. The WVTR results showed that the $0.5 \mathrm{wt} \%$ of MWNT-added UV epoxy resin exhibited the lowest WVTR value of $19 \mathrm{~g} \mathrm{~m}^{-2}$ day $^{-1}$, as shown in Figure 4b, Figures S9 and S10. Furthermore, the OTR test results also reveal that the optimal MWNT amount to exhibit the best barrier ability against oxygen is $0.5 \mathrm{wt} \%$ (Figure S11). This indicates that a specific ratio of MWNT to UV epoxy resin must be used for the good barrier property, and adding excess MWNTs 
can reverse the barrier effect. There are several intermolecular interactions in the carbonbased nanostructures, such as the carbon nanotubes. The main interaction of the carbon nanotubes is the $\pi-\pi$ interaction, which represents one of the van der Waals forces [47]. However, the actual $\pi$ interactions appeared between polycyclic unsaturated molecules with 10-15 carbon atoms [48]. Therefore, the carbon interactions of $0.5 \mathrm{wt} \%$ of MWNTadded UV epoxy resin were strong. Moreover, the amount of internal porosity of epoxy resin was decreased by the hardened carbon interaction, and the quantity of the penetrated water molecules reduced consequentially. Conversely, if the ratio of the MWNT to UV epoxy resin was higher than the specific ratio of $0.5 \mathrm{wt} \%$, then the condensation of the MWNT [49] could hinder the UV light-based hardening process. The van der Waals interaction between the MWNT was stronger than the interaction between the MWNT and UV epoxy resin. Hence, the MWNT-added UV epoxy resin could be declined by UV irradiation, resulting in the accumulation of MWNTs on the surface [50]. Additionally, the permeation of the water molecules and oxygen was easier and led to the deterioration of the solar cell properties due to the decreased rigidity of epoxy resin at $1.0 \mathrm{wt} \%$ of the MWNT-added UV epoxy resin. Figure 4c shows that the $0.5 \mathrm{wt} \%$ of MWNT-added UV epoxy resin-based PSCs had a greater device stability than $1.0 \mathrm{wt} \%$ of MWNT-added UV epoxy resin-based PSCs and the reference PSCs without any MWNTs (Table 1). While the normalised power conversion efficiency (PCE) of the $0.5 \mathrm{wt} \%$ of MWNT-added UV epoxy resin-based PSCs decreased by approximately 30\% over the operating time of one week, the reference devices without the MWNT addition displayed a decrease in the normalised PCE of approximately $63 \%$. Furthermore, the $0.5 \mathrm{wt} \%$ of MWNT-added UV epoxy resin-based PSCs showed a high stability in all photovoltaic parameters, namely, $J_{\mathrm{SC}}, \mathrm{FF}$, and $V_{\mathrm{OC}}$ (Figure $4 \mathrm{~d}$ and Figures S12-S14). In the case of $0.2 \mathrm{wt} \%$ MWNT-added epoxy resin-based devices, the improvement in stability was not clearly visible. We ascribed this to the added amount being too small (Figure S15). The results indicated that the addition of MWNT to the UV epoxy resin increased the barrier's ability against moisture and oxygen and released heat better. However, adding MWNTs greater than $0.5 \mathrm{wt} \%$ exacerbated the device stability.

(a) Pristine resin

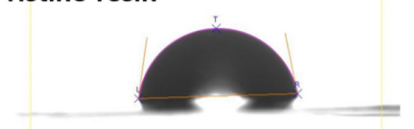

MWNT + resin

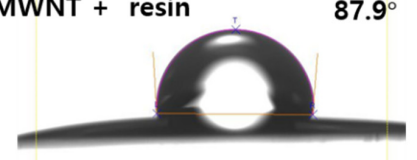

(b)

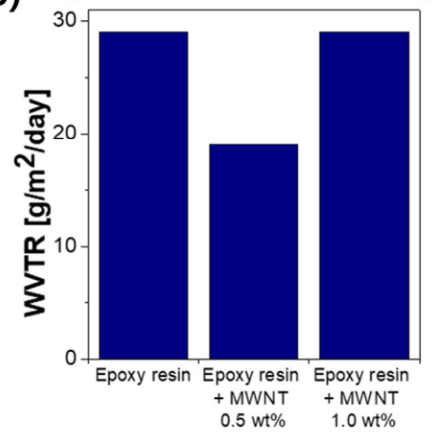

(c)

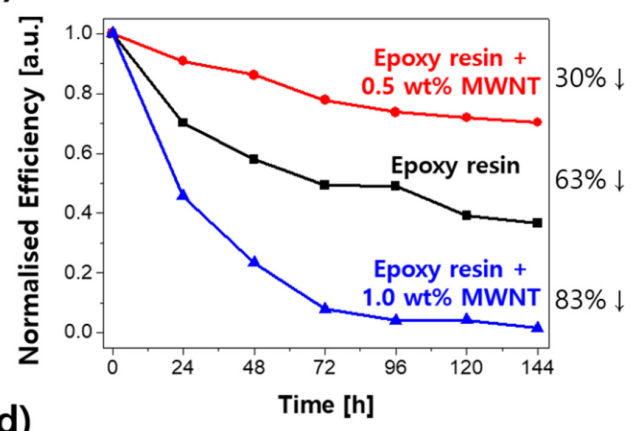

(d)

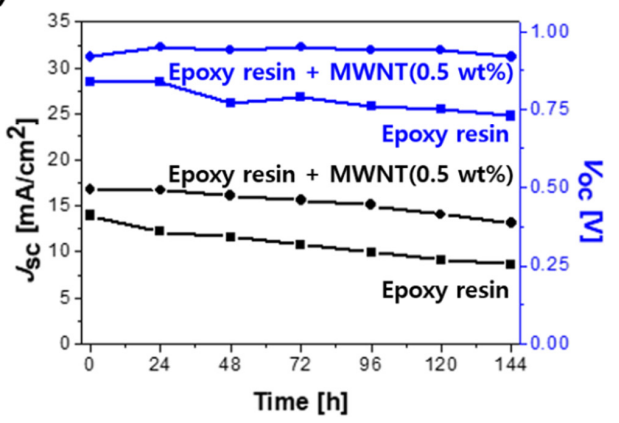

Figure 4. (a) Water contact angle of the pristine and MWNT-added UV epoxy resin; (b) WVTR of the MWNT-added UV epoxy resin; (c,d) Changes in (c) the normalised efficiency; (d) $J_{\mathrm{SC}}$ and $V_{\mathrm{OC}}$ of the encapsulated PSCs without (control device) and with MWNT added to the UV epoxy resin during the stability test under constant device operation. 


\section{Materials and Methods}

\subsection{PSC Fabrication}

Patterned ITO/glass substrates with a dimension of $1.5 \mathrm{~cm} \times 1.5 \mathrm{~cm}$ were cleaned by sonication with deionised water, acetone, and isopropyl alcohol for $10 \mathrm{~min}$, respectively. After drying, the substrates were attached with heat resistant tape. A $30 \mu \mathrm{L}$ solution measured from a mixture of $2 \mathrm{mg}$ of PTAA (Sigma-Aldrich, St. Louis, MO, USA) and $500 \mu \mathrm{L}$ toluene (Sigma-Aldrich) was dropped onto the substrate. The substrate was spin-coated at $5000 \mathrm{rpm}$ for $30 \mathrm{~s}$ and subsequently annealed at $110^{\circ} \mathrm{C}$ for $10 \mathrm{~min}$ in a nitrogen-filled glove box. After the coating process, the samples underwent UV-ozone treatment for $3 \mathrm{~min}$ to treat the hydrophobic surface of the PTAA layer and advance the adhesion property between the PTAA and $\mathrm{FACsPbI}_{3}$ Perovskite layer. The perovskite solution was prepared using $26 \mathrm{mg}$ cesium iodide powder (CsI, Sigma-Aldrich), $154.8 \mathrm{mg}$ formamidinium iodide powder (FAI, Greatcell Solar, Queanbeyan, Australia), $461 \mathrm{mg}$ lead iodide $\left(\mathrm{PbI}_{2}\right.$, Tokyo Chemical Industry, Tokyo, Japan), $74 \mu \mathrm{L}$ dimethyl sulfoxide (DMSO), and $580 \mu \mathrm{L} \mathrm{N,N-}$ dimethylformamide (DMF, Sigma-Aldrich). The mixture was subsequently annealed for 40-60 min at $100{ }^{\circ} \mathrm{C}$. A $35 \mu \mathrm{L}$ perovskite solution was dropped onto the substrate and spin-coated at $6000 \mathrm{rpm}$ for $20 \mathrm{~s}$. About $10 \mathrm{~s}$ into the coating process, $1.75 \mu \mathrm{L}$ of diethyl ether was sequentially dropped closer to the substrate. For the formation of the perovskite layer, the substrate was annealed for $1 \mathrm{~min}$ at $100{ }^{\circ} \mathrm{C}$. The temperature was subsequently raised to $155^{\circ} \mathrm{C}$ and maintained for $9 \mathrm{~min}$. This was followed by spin-coating PCBM solution with a concentration of $10 \mathrm{mg} \mathrm{mL}^{-1}$ in chlorobenzene at an rpm of 3000 for $30 \mathrm{~s}$. $\mathrm{C}_{60}, \mathrm{BCP}$, and silver were deposited consecutively with a photomask by thermal evaporation at a speed of $5 \AA \mathrm{s}^{-1}$. For the encapsulation, the epoxy resin was spread on the edge of the cover glass with a dimension of $1.1 \mathrm{~cm} \times 1.1 \mathrm{~cm}$. The cover glass was then placed on top of the PSC in the central part of the cell. After the capping process, the cover glass was cured by UV light for $10 \mathrm{~min}$. The current-voltage properties were analysed by contacting the external side of the silver electrode, which was exposed from the capped cover glass.

\subsection{Encapsulant}

The UV curable epoxy resin used to encapsulate the inverted PSC was purchased from Nagase ChemteX Corporation (XNR5516Z, Osaka Prefecture, Japan). MWNTs were purchased from CNT Co. Ltd. (Seoul, Korea). According to the technical sheet of the product, the outer diameters were $10 \mathrm{~nm}-140 \mathrm{~nm}$, the tube lengths were 5-20 $\mu \mathrm{m}$, and the purity was $>99 \%$ [51-53].

\subsection{Characterisations}

The $J-V$ curves were measured using a software-controlled source meter (Keithley 2400 Source-Meter) under dark conditions and the simulated sunlight irradiation of 1 sun (AM 1.5 G; $100 \mathrm{~mW} \mathrm{~cm}^{-2}$ ), which was generated from a solar simulator (EMS-35AAA, Ushio Spax Inc., Tokyo, Japan) with an Ushio Xe short arc lamp 500. The source meter was calibrated using a silicon diode (BS-520BK, Bunkokeiki, Tokyo, Japan). A photomask with a dimension of $3 \mathrm{~mm} \times 3 \mathrm{~mm}$ was placed for the measurement, which defined the active area. The long-term stability test was conducted by leaving the devices in a room where the temperature was ca. $25^{\circ} \mathrm{C}$ and the relative humidity was ca. $80 \%$ under constant illumination of sunlight. The external quantum efficiency (EQE) measurement system consisted of an MLS-1510 monochromator to scan the UV-Vis spectra. The crosssectional images of the epoxy resin spread between the device, substrate, and cover glass were obtained by SEM (Hitachi High Technologies, Tokyo, Japan. S-4800). The currentvoltage measurements were performed using a source meter (Agilent Technologies, Santa Clara, CA, USA. 4156C) under the illumination of simulated sunlight provided by an Oriel solar simulator equipped with an AM 1.5 G filter. The hydrophobic/hydrophilic properties of the epoxy resin and MWNT-added epoxy resin were measured using a Water contact angle analysis system. The WVTRs were measured using a Lyssy water vapour permeation analyser. 


\section{Conclusions}

The inverted PSCs were fabricated, encapsulated, and monitored for their stability. A trace amount of MWNTs was added to the UV-curable epoxy resin during the packaging process to improve the barrier and heat-releasing properties of the epoxy resin, thereby protecting the devices from degradation through moisture, oxygen, and heat. Furthermore, we investigated the water and oxygen permeability and the thermal conductivity of the resin. Despite the degradation caused by moisture and oxygen being a dominant factor, the trapped heat was significant enough to accelerate the degradation. Thus, our work proposes a novel engineering approach to encapsulation technology with the potential to advance the commercialisation of electronics, especially thin-film photovoltaics.

Supplementary Materials: The following are available online, 1. Light Absorbance Stability of Devices; 2. Encapsulation Approaches; 3. Stability of Devices with Different Passivation Structures; 4. Devices with Different Structures; 5. Devices with Different Applied Pressures; 6. Performance of Unencapsulated Devices; 7. Images of MWNT added UV-epoxy resin; 8. WVTR Data; 9. WVTR Sample Preparation; 10. OTR Data; 11 . $J_{\mathrm{SC}}$ and $V_{\mathrm{OC}}$ during Stability Test; 12 . Performance of $0.5 \mathrm{wt} \%$ MWNT-added Encapsulated Devices; and 13. Stability of $0.2 \mathrm{wt} \%$ MWNT-added Encapsulated Devices.

Author Contributions: Conceptualization, I.J. and H.D.; formal analysis, J.-M.C. and H.S.; investigation, J.-M.C. and H.S.; resources, Y.M. and S.M.; writing-original draft preparation, J.-M.C. and I.J.; writing-review and editing, J.-M.C., K.K., J.H., S.L., Y.M., S.M., I.J., H.D.; supervision, I.J. and H.D. All authors have read and agreed to the published version of the manuscript.

Funding: This research was supported by Pusan National University Research Grant, 2020.

Institutional Review Board Statement: Not applicable.

Informed Consent Statement: Not applicable.

Data Availability Statement: Not applicable.

Acknowledgments: This study was supported by the National Research Foundation of Korea funded by the Ministry of Science and ICT (MSIT), Korea (NRF-2021R1C1C1009200, 2020R1A6A3A01099709). This work was supported by Pusan National University Research Grant, 2020. We also thank the Japan Society for the Promotion of Science (JSPS) KAKENHI Grant Number JP15H05760, JP20H00220, and by JST, CREST Grant Number JPMJCR20B5, Japan. This research was supported by Pusan National University Research Grant, 2020.

Conflicts of Interest: The authors declare no conflict of interest.

Sample Availability: Samples of the compounds are not available.

\section{References}

1. Boix, P.P.; Nonomura, K.; Mathews, N.; Mhaisalkar, S.G. Current progress and future perspectives for organic/inorganic perovskite solar cells. Mater. Today 2014, 17, 16-23. [CrossRef]

2. Yang, Q.; Dettori, R.; Yuan, G.; Anderson, L.R. A perovskite solar cell owing very high stabilities and power conversion efficiencies. Sol. Energy 2020, 201, 541-546. [CrossRef]

3. Lee, C.; Lee, S.W.; Bae, S.; Shawky, A.; Devaraj, V.; Anisimov, A.; Kauppinen, E.I.; Oh, J.W.; Kang, Y.; Kim, D.; et al. Carbon Nanotube Electrode-Based Perovskite-Silicon Tandem Solar Cells. Sol. RRL 2020, 4, 2000353. [CrossRef]

4. Xing, G.; Mathews, N.; Lim, S.S.; Lam, Y.M.; Mhaisalkar, S.; Sum, T.C. Long-Range Balanced Electron- and Hole-Transport Lengths in Organic-Inorganic $\mathrm{CH}_{3} \mathrm{NH}_{3} \mathrm{PbI}_{3}$. Science 2013, 342, 344-347. [CrossRef]

5. Thote, A.; Jeon, I.; Lin, H.S.; Manzhos, S.; Nakagawa, T.; Suh, D.; Hwang, J.; Kashiwagi, M.; Shiomi, J.; Maruyama, S.; et al. High-Working-Pressure Sputtering of ZnO for Stable and Efficient Perovskite Solar Cells. ACS Appl. Electron. Mater. 2019, 1, 389-396. [CrossRef]

6. Jeon, I.; Shawky, A.; Lin, H.S.; Seo, S.; Okada, H.; Lee, J.W.; Pal, A.; Tan, S.; Anisimov, A.; Kauppinen, E.I.; et al. Controlled Redox of Lithium-Ion Endohedral Fullerene for Efficient and Stable Metal Electrode-Free Perovskite Solar Cells. J. Am. Chem. Soc. 2019, 141, 16553-16558. [CrossRef] [PubMed]

7. Jeon, I.; Ueno, H.; Seo, S.; Aitola, K.; Nishikubo, R.; Saeki, A.; Okada, H.; Boschloo, G.; Maruyama, S.; Matsuo, Y. Lithium-Ion Endohedral Fullerene (Li+@C60) Dopants in Stable Perovskite Solar Cells Induce Instant Doping and Anti-Oxidation. Angew. Chem. Int. Ed. 2018, 57, 4607-4611. [CrossRef] [PubMed] 
8. Ahn, N.; Kwak, K.; Jang, M.S.; Yoon, H.; Lee, B.Y.; Lee, J.K.; Pikhitsa, P.V.; Byun, J.; Choi, M. Trapped charge-driven degradation of perovskite solar cells. Nat. Commun. 2016, 7, 13422. [CrossRef] [PubMed]

9. Ahn, N.; Jeon, I.; Yoon, J.; Kauppinen, E.I.; Matsuo, Y.; Maruyama, S.; Choi, M. Carbon-sandwiched perovskite solar cell. J. Mater. Chem. A 2018, 6, 1382-1389. [CrossRef]

10. Jena, A.K.; Numata, Y.; Ikegami, M.; Miyasaka, T. Role of spiro-OMeTAD in performance deterioration of perovskite solar cells at high temperature and reuse of the perovskite films to avoid Pb-waste. J. Mater. Chem. A 2018, 6, 2219-2230. [CrossRef]

11. Lin, H.S.; Jeon, I.; Xiang, R.; Seo, S.; Lee, J.W.; Li, C.; Pal, A.; Manzhos, S.; Goorsky, M.S.; Yang, Y.; et al. Achieving High Efficiency in Solution-Processed Perovskite Solar Cells Using C60/C70 Mixed Fullerenes. ACS Appl. Mater. Interfaces 2018, 10, 39590-39598. [CrossRef] [PubMed]

12. Conings, B.; Drijkoningen, J.; Gauquelin, N.; Babayigit, A.; D’Haen, J.; D’Olieslaeger, L.; Ethirajan, A.; Verbeeck, J.; Manca, J.; Mosconi, E.; et al. Intrinsic Thermal Instability of Methylammonium Lead Trihalide Perovskite. Adv. Energy Mater. 2015, 5, 1500477. [CrossRef]

13. Norrman, K.; Madsen, M.V.; Gevorgyan, S.A.; Krebs, F.C. Degradation patterns in water and oxygen of an inverted polymer solar cell. J. Am. Chem. Soc. 2010, 132, 16883-16892. [CrossRef] [PubMed]

14. Adams, J.; Spyropoulos, G.D.; Salvador, M.; Li, N.; Strohm, S.; Lucera, L.; Langner, S.; MacHui, F.; Zhang, H.; Ameri, T.; et al. Air-processed organic tandem solar cells on glass: Toward competitive operating lifetimes. Energy Environ. Sci. 2015, 8, 169-176. [CrossRef]

15. Adams, J.; Salvador, M.; Lucera, L.; Langner, S.; Spyropoulos, G.D.; Fecher, F.W.; Voigt, M.M.; Dowland, S.A.; Osvet, A.; Egelhaaf, H.J.; et al. Water ingress in encapsulated inverted organic solar cells: Correlating infrared imaging and photovoltaic performance. Adv. Energy Mater. 2015, 5, 1501065. [CrossRef]

16. Burrows, P.E.; Bulovic, V.; Forrest, S.R.; Sapochak, L.S.; McCarty, D.M.; Thompson, M.E. Reliability and degradation of organic light emitting devices. Appl. Phys. Lett. 1994, 65, 2922-2924. [CrossRef]

17. Roesch, R.; Eberhardt, K.R.; Engmann, S.; Gobsch, G.; Hoppe, H. Polymer solar cells with enhanced lifetime by improved electrode stability and sealing. Sol. Energy Mater. Sol. Cells 2013, 117, 59-66. [CrossRef]

18. Hösel, M.; Søndergaard, R.R.; Jørgensen, M.; Krebs, F.C. Comparison of UV-curing, hotmelt, and pressure sensitive adhesive as roll-to-roll encapsulation methods for polymer solar cells. Adv. Eng. Mater. 2013, 15, 1068-1075. [CrossRef]

19. Roppolo, I.; Shahzad, N.; Sacco, A.; Tresso, E.; Sangermano, M. Multifunctional NIR-reflective and self-cleaning UV-cured coating for solar cell applications based on cycloaliphatic epoxy resin. Prog. Org. Coat. 2014, 77, 458-462. [CrossRef]

20. Abd-Elnaiem, A.M.; Hussein, S.I.; Assaedi, H.S.; Mebed, A.M. Fabrication and evaluation of structural, thermal, mechanical and optical behavior of epoxy-TEOS/MWCNTs composites for solar cell covering. Polym. Bull. 2021, 78, 3995-4017. [CrossRef]

21. Iijima, S. Helical microtubules of graphitic carbon. Nature 1991, 354, 56-58. [CrossRef]

22. Jeon, I.; Matsuo, Y.; Maruyama, S. Single-Walled Carbon Nanotubes in Solar Cells. Top. Curr. Chem. 2018, 376, 4. [CrossRef]

23. Jeon, I.; Xiang, R.; Shawky, A.; Matsuo, Y.; Maruyama, S. Single-Walled Carbon Nanotubes in Emerging Solar Cells: Synthesis and Electrode Applications. Adv. Energy Mater. 2019, 9, 1801312. [CrossRef]

24. Könemann, F.; Vollmann, M.; Wagner, T.; Mohd Ghazali, N.; Yamaguchi, T.; Stemmer, A.; Ishibashi, K.; Gotsmann, B. Thermal Conductivity of a Supported Multiwalled Carbon Nanotube. J. Phys. Chem. C 2019, 123, 12460-12465. [CrossRef]

25. Kumanek, B.; Janas, D. Thermal conductivity of carbon nanotube networks: A review. J. Mater. Sci. 2019, 54, 7397-7427. [CrossRef]

26. Moisala, A.; Li, Q.; Kinloch, I.A.; Windle, A.H. Thermal and electrical conductivity of single- and multi-walled carbon nanotubeepoxy composites. Compos. Sci. Technol. 2006, 66, 1285-1288. [CrossRef]

27. Kakade, B.A.; Pillai, V.K. Tuning the wetting properties of multiwalled carbon nanotubes by surface functionalization. J. Phys. Chem. C 2008, 112, 3183-3186. [CrossRef]

28. Yang, W.; Zhong, D.; Shi, M.; Qu, S.; Chen, H. Toward Highly Thermal Stable Perovskite Solar Cells by Rational Design of Interfacial Layer. iScience 2019, 22, 534-543. [CrossRef] [PubMed]

29. Dao, Q.D.; Tsuji, R.; Fujii, A.; Ozaki, M. Study on degradation mechanism of perovskite solar cell and their recovering effects by introducing $\mathrm{CH}_{3} \mathrm{NH}_{3} \mathrm{I}$ layers. Org. Electron. 2017, 43, 229-234. [CrossRef]

30. Shirayama, M.; Kato, M.; Miyadera, T.; Sugita, T.; Fujiseki, T.; Hara, S.; Kadowaki, H.; Murata, D.; Chikamatsu, M.; Fujiwara, H. Degradation mechanism of $\mathrm{CH}_{3} \mathrm{NH}_{3} \mathrm{PbI}_{3}$ perovskite materials upon exposure to humid air. J. Appl. Phys. 2016, 119, 115501. [CrossRef]

31. Raga, S.R.; Jung, M.C.; Lee, M.V.; Leyden, M.R.; Kato, Y.; Qi, Y. Influence of air annealing on high efficiency planar structure perovskite solar cells. Chem. Mater. 2015, 27, 1597-1603. [CrossRef]

32. Niu, G.; Li, W.; Meng, F.; Wang, L.; Dong, H.; Qiu, Y. Study on the stability of $\mathrm{CH}_{3} \mathrm{NH}_{3} \mathrm{PbI}_{3}$ films and the effect of post-modification by aluminum oxide in all-solid-state hybrid solar cells. J. Mater. Chem. A 2014, 2, 705-710. [CrossRef]

33. Dou, Y.; Xu, H.; Liu, Y.; Wang, M.; Zhang, J.; Ovchinnikova, O.S.; Hu, B. Tuning spin-orbit coupling towards enhancing photocurrent in hybrid organic-inorganic perovskites by using mixed organic cations. Org. Electron. 2020, 81, 105671. [CrossRef]

34. Boyd, C.C.; Cheacharoen, R.; Leijtens, T.; McGehee, M.D. Understanding Degradation Mechanisms and Improving Stability of Perovskite Photovoltaics. Chem. Rev. 2019, 119, 3418-3451. [CrossRef]

35. Jeon, I.; Chiba, T.; Delacou, C.; Guo, Y.; Kaskela, A.; Reynaud, O.; Kauppinen, E.I.; Maruyama, S.; Matsuo, Y. Single-Walled Carbon Nanotube Film as Electrode in Indium-Free Planar Heterojunction Perovskite Solar Cells: Investigation of Electron-Blocking Layers and Dopants. Nano Lett. 2015, 15, 6665-6671. [CrossRef] 
36. Jeon, I.; Nakao, S.; Hirose, Y.; Hasegawa, T.; Matsuo, Y. Indium-Free Inverted Organic Solar Cells Using Niobium-Doped Titanium Oxide with Integrated Dual Function of Transparent Electrode and Electron Transport Layer. Adv. Electron. Mater. 2016, 2, 2-7. [CrossRef]

37. Ava, T.T.; Al Mamun, A.; Marsillac, S.; Namkoong, G. A review: Thermal stability of methylammonium lead halide based perovskite solar cells. Appl. Sci. 2019, 9, 188. [CrossRef]

38. Rau, U.; Paetzold, U.W.; Kirchartz, T. Thermodynamics of light management in photovoltaic devices. Phys. Rev. B 2014, 90, 035211. [CrossRef]

39. Mehdizadeh-Rad, H.; Singh, J. Influence of interfacial traps on the operating temperature of perovskite solar cells. Materials 2019, 12, 2727. [CrossRef]

40. Reyna, Y.; Salado, M.; Kazim, S.; Pérez-Tomas, A.; Ahmad, S.; Lira-Cantu, M. Performance and stability of mixed $\mathrm{FAPbI}_{3(0.85)} \mathrm{MAPbBr}_{3(0.15)}$ halide perovskite solar cells under outdoor conditions and the effect of low light irradiation. Nano Energy 2016, 30, 570-579. [CrossRef]

41. Park, J.G.; Cheng, Q.; Lu, J.; Bao, J.; Li, S.; Tian, Y.; Liang, Z.; Zhang, C.; Wang, B. Thermal conductivity of MWCNT/epoxy composites: The effects of length, alignment and functionalization. Carbon 2021, 50, 2083-2090. [CrossRef]

42. Huang, C.; Zhen, W.; Huang, Z.; Luo, D. Thermal and electrical conductivities of epoxy resin-based composites incorporated with carbon nanotubes and $\mathrm{TiO}_{2}$ for a thermoelectric application. Appl. Phys. A 2018, 124, 38. [CrossRef]

43. Green, M.A.; Emery, K.; Hishikawa, Y.; Warta, W.; Dunlop, E.D. Solar cell efficiency tables (version 40). Prog. Photovolt. Res. Appl. 2012, 20, 606-614. [CrossRef]

44. Polman, A.; Atwater, H.A. Photonic design principles for ultrahigh-efficiency photovoltaics. Nat. Mater. 2012, 11, 174-177. [CrossRef]

45. Choi, K.; Lee, J.; Kim, H.I.; Park, C.W.; Kim, G.W.; Choi, H.; Park, S.; Park, S.A.; Park, T. Thermally stable, planar hybrid perovskite solar cells with high efficiency. Energy Environ. Sci. 2018, 11, 3238-3247. [CrossRef]

46. Youssry, M.; Al-Ruwaidhi, M.; Zakeri, M.; Zakeri, M. Physical functionalization of multi-walled carbon nanotubes for enhanced dispersibility in aqueous medium. Emerg. Mater. 2020, 3, 25-32. [CrossRef]

47. Pérez, E.M.; Martín, N. $\pi-\pi$ interactions in carbon nanostructures. Chem. Soc. Rev. 2015, 44, 6425-6433. [CrossRef]

48. Grimme, S. Do special noncovalent $\pi-\pi$ stacking interactions really exist? Angew. Chem. Int. Ed. 2008, 47, 3430-3434. [CrossRef]

49. Yang, Q.S.; He, X.Q.; Liu, X.; Leng, F.F.; Mai, Y.W. The effective properties and local aggregation effect of CNT/SMP composites. Compos. Part B Eng. 2012, 43, 33-38. [CrossRef]

50. Nguyen, T.; Petersen, E.J.; Pellegrin, B.; Gorham, J.M.; Lam, T.; Zhao, M.; Sung, L. Impact of UV irradiation on multiwall carbon nanotubes in nanocomposites: Formation of entangled surface layer and mechanisms of release resistance. Carbon 2017, 116, 191-200. [CrossRef] [PubMed]

51. Dembele, K.T.; Selopal, G.S.; Soldano, C.; Nechache, R.; Rimada, J.C.; Concina, I.; Sberveglieri, G.; Rosei, F.; Vomiero, A. Hybrid Carbon Nanotubes-TiO 2 Photoanodes for High Efficiency Dye-Sensitized Solar Cells. J. Phys. Chem. C 2013, 117, 14510-14517. [CrossRef]

52. Mohammadnezhad, M.; Selopal, G.S.; Wang, Z.M.; Stansfield, B.; Zhao, H.; Rosei, F. Role of Carbon Nanotubes to Enhance the Long-Term Stability of Dye-Sensitized Solar Cells. ACS Photonics 2020, 7, 653-664. [CrossRef]

53. Mohammadnezhad, M.; Selopal, G.S.; Wang, Z.M.; Stansfield, B.; Zhao, H.; Rosei, F. Towards Long-Term Thermal Stability of Dye-Sensitized Solar Cells Using Multiwalled Carbon Nanotubes. ChemPlusChem 2018, 83, 682-690. [CrossRef] [PubMed] 